\title{
A surface plasmon resonance biosensor for direct detection of the rabies virus
}

\author{
Jing Xu' ${ }^{1}$, Jia-yu Wan ${ }^{1}$, Song-tao Yang ${ }^{1}$, Shou-feng Zhang ${ }^{1}, \mathrm{Na} \mathrm{Xu}^{3}$, Nan $\mathrm{Li}^{1}$, \\ Ji-ping $\mathrm{Li}^{1}$, Hai-ying Wang ${ }^{2}$, Xue Bai ${ }^{2}$, Wen-sen Liu ${ }^{1}$ \\ ${ }^{1}$ Institute of Military Veterinary Science, Academy of Military Medical Science, Changchun, Jilin, P. R. China, \\ Key Laboratory of Jilin province for Zoonosis Prevention and Control, Changchun, Jilin, P. R. China \\ ${ }^{2}$ College of Animal Science and Veterinary Medicine, Changchun, Jilin, P. R. China \\ ${ }^{3}$ Jilin Medical College, Jilin, P. R. China \\ Received October 14, 2011 \\ Accepted March 7, 2012
}

\begin{abstract}
A surface plasmon resonance biosensor chip was constructed for detection of rabies virus. For the construction of the biosensor chip, $\mathrm{N}$ protein specific antibody and $\mathrm{N}$ protein specific antibody combined with $\mathrm{G}$ protein specific antibody of rabies virus were linked on two different flow cells on one CM5 chip, respectively. The chip was tested for the detection of rabies virus antigens using the crude extract of rabies virus from infected BHK cell strain culture. Tenfold serial dilutions of $\mathrm{SRV}_{9}$ strain virus-infected cell cultures were tested by the biosensor chip to establish the detection limit. The limit detection was approximately $70 \mathrm{pg} / \mathrm{ml}$ of nucleoprotein and glycoprotein. The biosensor chip developed in this study was employed for the detection of rabies virus in five suspect infectious specimens of brain tissue from guinea pigs; the results were compared by fluorescent antibody test. Surface plasmon resonance biosensor chip could be a useful automatic tool for prompt detection of rabies virus infection.
\end{abstract}

CM5 chip, SRV , nucleoprotein, glycoprotein

The rabies virus is a neurotropic virus that causes rabies, a fatal disease in humans and animals that may be transmitted through the saliva of infected animals. There is no specific anti-viral treatment when central nervous system (CNS) symptoms developed caused by rabies virus, and the mortality rate from rabies is close to $100 \%$ (Rodney et al. 2005). Therefore, the development of highly specific and rapid techniques for the diagnosis of rabies is still of major importance for the control of this disease. The rabies virus genome encodes five structural proteins: nucleoprotein (NP), phosphoprotein (PP), matrix protein (MP), glycoprotein (GP), and RNA-dependent RNA polymerase $(\mathrm{L})$. The NP is highly antigenically conserved among all rabies virus strains and the GP is the most relevant antigen for eliciting the production of cell-mediated immunity by cytotoxic $\mathrm{T}$ lymphocytes and $\mathrm{T}$ helper cells. Thus, the presence of these two antigens has been monitored in rabies clinical diagnostics.

Surface plasmon resonance (SPR) is a promising tool in sensor technology for biomedical applications due to its capability for rapid, label-free and automatic detection. There are several reports on virus diagnosis by SPR, which shows effective (Kumbhat 2010). Usually, antigen detection-based assays for rabies detection, such as the direct rapid immunohistochemical test (dRIT) (Niezgoda and Rupprecht 2006), employ anti-rabies mAbs specific for NP. However, in this study, an SPR biosensor chip linked with antiRABV mAbs was developed for the prompt monitoring of the antigens (the antigens of NP and GP) of the RABV in either cell culture fluid or brain tissue homogenate.

\section{Materials and Methods}

Reagents and biosensor system

The $\mathrm{SRV}_{9}$ strain (GenBank Accession No.AF499686) is a candidate vaccine strain, cloned from SAD B-19. Mouse monoclonal antibodies IgG 9G3 and 9C3 were specific against NP and GP, respectively (Zhang 2006, 2009). Five suspect specimens from rabies virus-infected guinea pig brains were identified by the fluorescent

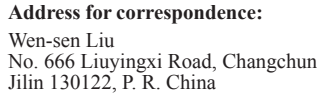

Phone: 18943614766

E-mail: liuws85952@163.com

http://actavet.vfu.cz/ 
antibody test (FAT). The $\mathrm{SRV}_{9}$ strain, monoclonal antibodies and suspect specimens were all presented by the lab. Epidem, Vet Inst, Changchun, China. and stored at $-80^{\circ} \mathrm{C}$. Biomolecular Interaction Analysis (Biacore) 3000 system, Hepes-buffered saline with EDTA and surfactant (HBS-EP, $10 \mathrm{mM}$ HEPES with pH 7.4, 150 $\mathrm{mM} \mathrm{NaCl}, 3 \mathrm{mM}$ EDTA, $0.005 \%$ surfactant P20), the CM5 sensor chip, and Biacore amine coupling kit, which includes N-hydroxyl-succinimide (NHS), N-ethyl-N-(3-diethylaminopropyl) carbodiimide (EDC), ethanolamine hydrochloride, acetate buffer and glycine-HCl buffer, were all obtained from Biacore AB (Uppsala, Sweden). Sepharose 4 fast flow gel from Pharmacia Corp. and 30,000 NMWC hollow fibre columns from Amersham Biosciences Corp.

Crude rabies virus preparation

Other proteins or impurities except for rabies virus antigen in the analyte would not impact the specific reaction between virus antigens and antibodies on the surface of the sensor chip, so we prepared the crude extract of rabies virus as the analyte. $\mathrm{A} \mathrm{SRV}_{9}$-propagated strain was passaged on BHK-21 cells, as previously described by King et al. (1996). Infected cells were frozen and thawed three times, culture fluid was collected, and virus present in the culture fluid was inactivated by treating it with 1:4000 $\beta$-propiolactone at $4{ }^{\circ} \mathrm{C}$ for $36 \mathrm{~h}$, with any remaining $\beta$-propiolactone being hydrolyzed by incubation at $37{ }^{\circ} \mathrm{C}$ for $2 \mathrm{~h}$. The cells were separated by centrifugation $\left(4{ }^{\circ} \mathrm{C}, 2991 \times \mathrm{g}, 30 \mathrm{~min}\right)$, and the supernatant was collected. The inactivated virus suspension was filtered by a $0.45 \mathrm{~mm}$ filter membrane, concentrated 20 -fold by a 30,000 NMWC hollow fibre column, separated by Sepharose 4FF (bed length $400 \mathrm{~mm}$, i.d. $26 \mathrm{~mm}$ ) sieve chromatography, and identified by transmission electron microscope (TEM) negative staining analysis and Western blot (Sambrook et al. 1989) with mAbs against NP and GP of RABV and pools of the virus harvest were aliquoted, freeze-dried and stored at $-80{ }^{\circ} \mathrm{C}$.

Polyacrylamide gel electrophoresis (PAGE) of the two mAbs

Before binding the antibodies to the biosensor chip, we identified the molecular weight (MW) of the mAbs. The NP and GP specific antibodies were fractionated by sodium dodecyl sulfate-polyacrylamide gel electrophoresis (SDS-PAGE) with 8\% (wt./vol.) of acrylamide/bis 30\% gels. Protein electrophoretic profiles in gel were stained with Coomassie Blue R-250, and the bands were scanned using a densitometer (Bio-rad System and Imagemaster 1D software).

\section{Construction of biosensor chip}

All experiments with the CM5 biosensor chip were conducted at $25^{\circ} \mathrm{C}$, and HBS-EP buffer as balanced solution flowed via the flow cells on sensor chip before and after it was exposed to samples. The chip was activated via treatment with an equal mixture of freshly prepared $0.4 \mathrm{M} \mathrm{EDC}$ and $0.1 \mathrm{M} \mathrm{NHS}$ for $6 \mathrm{~min}$ at $5 \mathrm{ml} / \mathrm{min}$, after which the surface was washed with HBS-EP buffer. The NP specific antibodies were immobilized on Flow Cell 2 (FC2), and NP specific antibody combined with GP specific antibody of RABV were immobilized on Flow Cell 3 (FC3), with Flow Cell 1 (FC1) as a reference sample channel (without any antibody being immobilized on it). The mAbs were immobilized as follows: the mAb solution $(30 \mathrm{mg} / \mathrm{ml}$, with $30 \mathrm{ng} / \mathrm{ml}$ human serum albumin as protectant) in $10 \mathrm{mM}$ acetate buffer ( $\mathrm{pH} 5.0$ ), was injected for $10 \mathrm{~min}$ at $10 \mathrm{ml} / \mathrm{min}$. The chip was subsequently treated with $1 \mathrm{M}$ ethanolamine- $\mathrm{HCl}(\mathrm{pH} 8.5)$ for $6 \mathrm{~min}$ at $10 \mathrm{ml} / \mathrm{min}$ to block any unreacted activated carboxyl groups; then it was washed with HBS-EP buffer for $2 \mathrm{~min}$ at $20 \mathrm{ml} / \mathrm{min}$.

Comparison of the two mAb-linked flow cells

Two mAb-linked flow cells were evaluated by injecting the crude extract of RABV at various concentrations (freeze-dried rabies virus was dissolved and diluted by HBS-EP buffer from $1000 \mathrm{mg} / \mathrm{ml}$ to $1.95 \mathrm{mg} / \mathrm{ml}$ in twofold dilutions) into FC1, FC2 and FC3 for $3 \mathrm{~min}$ at $10 \mathrm{ml} / \mathrm{min}$, simultaneously. Three replicates were run for every injection. The data obtained for FC1 were subtracted from those obtained for FC2 and FC3. Statistical Product and Service Solutions (SPSS) software (version 11.0) was used for the statistical analysis. The bound RABV was removed by $15 \mathrm{ml}$ of $10 \mathrm{mM}$ glycine- $\mathrm{HCl}(\mathrm{pH} 2.5)$ after each sample assay.

\section{Surface plasmon resonance assay}

To evaluate the detection limit of the developed biosensor chip, the $\mathrm{SRV}_{9}$-propagated strain was passaged on BHK-21 cells, and the concentration of the prepared RABV was measured by determining the $50 \%$ tissue culture infective dose (TCID50) per milliliter in BHK-21 cells, which followed the protocols described by Rosenbaum (1970), and tenfold serial dilutions of the virus in HBS-EP buffer were tested with the biosensor chip for $10 \mathrm{~min}$ at $10 \mathrm{ml} / \mathrm{min}$. The HBS-EP buffer was injected in the same way for the 10 replicates as blank samples. To establish the lower limit of detection, the TCID50 was determined for the highest dilution of the virus that tested positive with the biosensor chip.

Five specimens of suspect rabies virus infection were subjected to SPR analysis, and with one healthy guinea pig brain tissue as negative control. Each of the refrigerant brain tissues was thawed slowly at room temperature and treated as follows: homogenization in 3 volumes (w/v) of HBS-EP, centrifugation $\left(4^{\circ} \mathrm{C}, 2991 \times \mathrm{g}, 30 \mathrm{~min}\right)$, and collection of the supernatant, filtration by a $0.45 \mathrm{~mm}$ filter membrane. The supernatant from each brain tissue was injected into FC1 and FC3 for $10 \mathrm{~min}$ at $10 \mathrm{ml} / \mathrm{min}$, simultaneously.

Three replicates were run for every injection, with $15 \mathrm{ml}$ of $10 \mathrm{mM}$ glycine- $\mathrm{HCl}(\mathrm{pH} 2.5)$ as regeneration condition and $50 \mathrm{ml}$ of HBS-EP as balanced solution. 


\section{Results}

Identification of the crude extract of rabies virus

The fraction obtained via sieve chromatography in the process of crude extraction of the rabies virus was identified by TEM negative staining analysis. The fraction contained intact rabies virus particles and helical RNA-protein complexes (RNP), which were released from the membrane envelope of the RABV. Western blot showed that this crude extract of the rabies virus could react with both $\mathrm{mAb} N$ and $\mathrm{mAb} G$.

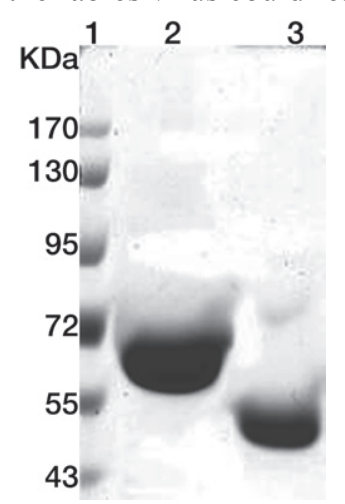

Fig. 1. SDS-

Polyacrylamide gelelectrophoresis (PAGE) of $\mathrm{mAb} \mathrm{N}$ and $\mathrm{mAb}$ G. Lane 1 molecular mass standards (Pharmacia); Lane 2 $\mathrm{mAb}$ N; Lane 3 - mAb G.
Fig. 1 shows that the molecular weight (MW) of mAbs N and $\mathrm{G}$ were approximately $60 \mathrm{kDa}$ and $50 \mathrm{kDa}$, respectively.

Binding of anti-RABV mAbs onto the biosensor chip By the construction of the biosensor chip, the results showed that the mAbs in the same concentration, binding onto each of the two activated flow cells, shifted to different SPR angles: the mAb (N) on FC2 shifted the SPR angle to 7753.8 RU, and the mAb mixture (N and G) on FC3 shifted the SPR angle to $8562.4 \mathrm{RU}$.

Evaluation of the two types of anti-RABV mAblinked flow cells

As shown in Fig. 2, at the range of concentrations of the crude extract of the RABV from $1.96 \mathrm{mg} / \mathrm{ml}$ to $125 \mathrm{mg} /$ $\mathrm{ml}$, the analyte shifted the SPR angle in a concentrationdependent manner on both flow cells. For FC2, the linear regression equation was $(\Delta \mathrm{RU}) \mathrm{y}=1.2183 \mathrm{x}+11.406$ $(\mathrm{R} 2=0.9958, \mathrm{n}=6)$, and for $\mathrm{FC} 3$, the linear regression equation was $(\Delta \mathrm{RU}) \mathrm{y}=4.3561 \mathrm{x}+7.5233(\mathrm{R} 2=0.9955$, $\mathrm{n}=6$ ), where $\mathrm{y}$ and $\mathrm{x}$ were the relative response units (RUs) and analyte concentrations, respectively. The slopes of the equations showed that sensitivity improved from 1.2183 to $4.3561 \mathrm{RU}$ per concentration unit $(\mathrm{mg} / \mathrm{ml})$. Sensitivity improved by a factor of 3.1378. All of the RU values of the triplicate experiments had no significant differences $(P>0.05)$.

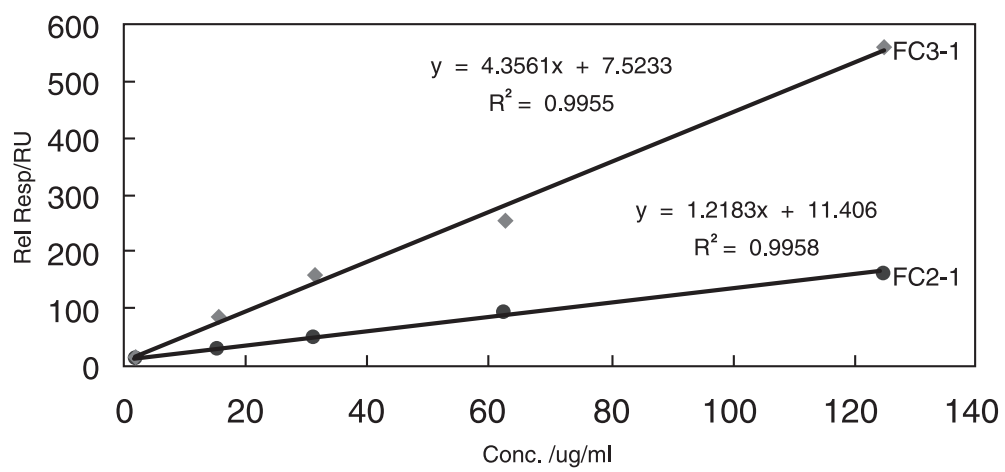

Fig. 2. Linear range of the immunoassay in Hepes-buffered saline with EDTA and surfactant (HBS-EP). FC21 and FC3-1 represent the mAb (N)-linked flow cell response and mAb mixture (N and $\mathrm{G})$-linked flow cell response, respectively 


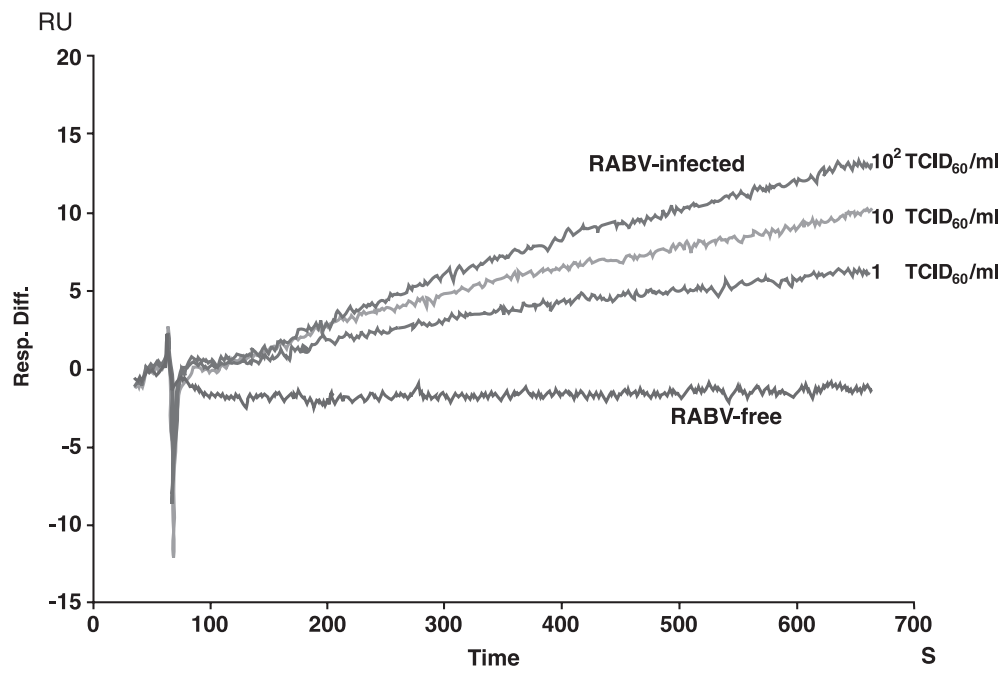

Fig. 3. Limit of detection for the anti-RABV biosensor chip.

\section{Detection limit}

The HBS-EP buffer was tested by the biosensor chip for 10 replicates as the blank samples. The data obtained for FC1 were subtracted from those obtained for FC3. The standard deviation (SD) of the blank sample was 1.52, and the limit of detection (LOD) was defined as the concentration of analyte that shifted the SPR angle to a point at which we could distinguish only a signal in the background, with this point usually beginning at 3 standard deviations (SD) from the blank (Thomsen et al. 2003). The infectivity of the $\mathrm{SRV}_{9}$ strain virus from the cell culture before dilution was $4 \times 10^{4} \mathrm{TCID} 50 / \mathrm{ml}$. Fig. 3 shows that for the mAb mixture $\left(\mathrm{N}\right.$ and $\mathrm{G}$ )-linked biosensor chip, the $4 \times 10^{4}$ dilution of the original RABV-infected culture fluid shifted the SPR angle to 5.9 RU, which just exceeded $4.56(3 \times \mathrm{SD})$. Therefore, $1 \mathrm{TCID} 50 / \mathrm{ml}$ was the detection limit of the $\mathrm{mAb}$ mixture $(\mathrm{N}$ and G)-linked flow cell (FC3).

Detection of the RABV from the brain tissue of guinea pigs

Table 1 shows that the negative control supernatant (No.6) shifted the SPR angle to 24.6 RU, and the critical value (CV) is 49.2 RU. The samples No.1 and No.3 that shifted the SPR angle less than 49.2 RU were confirmed to be virus-negative, and the samples No.2, No.4 and No.5 that shifted the SPR angle over the critical value were confirmed to be viruspositive. The data obtained for FC1 were subtracted from those obtained for FC3. All of the RU values of the triplicate experiments had no significant differences $(P>0.05)$. This result was confirmed by FAT.

Table 1. The specificity of surface plasmon resonance biosensor in assaying brain tissue from guinea pigs.

\begin{tabular}{cccccc}
\hline $\begin{array}{c}\text { Serial number } \\
\text { of sample }\end{array}$ & $\begin{array}{c}\text { SPR } \\
\text { (response units) }\end{array}$ & FAT & $\begin{array}{c}\text { Serial number } \\
\text { of sample }\end{array}$ & $\begin{array}{c}\text { SPR } \\
\text { (response units) }\end{array}$ & FAT \\
\hline No.1 & 44.9 & - & No.4 & 108.2 & ++ \\
No.2 & 1094.4 & ++++ & No.5 & 379.6 & ++ \\
No.3 & 16.2 & - & No.6 & 24.6 & - \\
\hline
\end{tabular}

$\mathrm{FAT}=$ fluorescent antibody test, $\mathrm{SPR}=$ surface plasmon resonance 


\section{Discussion}

For the construction of the biosensor chip, the results showed that the SPR angle shifted by the $\mathrm{mAb}$ mixture $(\mathrm{N}$ and $\mathrm{G})$ was $808.6 \mathrm{RU}$ higher than the $\mathrm{mAb}(\mathrm{N})$. After comparing the molecular weight of the two mAbs (N and $\mathrm{G}$ ) by SDS-PAGE, we found that mAb (N) was much larger than $\mathrm{mAb}(\mathrm{G})$. This finding implied that the mAb mixture $(\mathrm{N}$ and $\mathrm{G})$ would have much higher binding density and amount than mAb $(\mathrm{N})$ on each of the two activated flow cells at the same concentration. This high immobilization level would improve the sensitivity of detection to some extent. Furthermore, the mAb mixture (N and G) could detect the antigens on both NP and GP, and this ability could improve the detection rate more than the $\mathrm{mAb}(\mathrm{N})$-linked flow cell.

The detection limit of the SPR biosensor chip linked with the mAb mixture (N and $G)$ developed in this study was 1TCID50/ml, which shifted the SPR angle to 5.9 RU. For most proteins, $10000 \mathrm{RU}$ is equivalent to $10 \mathrm{ng} / \mathrm{mm}^{2}$ in coverage (Karlsson 1993); $5.9 \mathrm{RU}$ is equivalent to $5.9 \mathrm{pg} / \mathrm{mm}^{2}$, and the area of each flow cell on the CM5 chip was nearly $1.2 \mathrm{~mm}^{2}$. Therefore, the limit detection of our sensor was approximately $70 \mathrm{pg} / \mathrm{ml}$ of nucleoprotein and glycoprotein, while detection limit of enzyme-labeled immunosorbent assay (ELISA) was $2 \mathrm{ng} / \mathrm{ml}$ of glycoprotein (Fournier-Caruana et al. 2003). In conclusion, the SPR biosensor chip combined with a RABV mAb mixture ( $\mathrm{N}$ and $\mathrm{G}$ ) suggested superior performance and could serve as a rabies surveillance tool.

\section{Acknowledgments}

This work was supported by grant from the Ministry of Agriculture's special scientific fund for non-profit public industries (Project No. 200803014). We are very grateful to prof. Rong-liang Hu at the Laboratory of Epidemiology, Veterinary Institute, Academy of Military Medical Science, for generously providing the RABV preparation and monoclonal antibodies.

\section{References}

Fournier-Caruana J, Poirier B, Haond G, Jallet C, Fuchs F, Tordo N, Perrin P 2003: Inactivated rabies vaccine control and release: use of an ELISA method. Biologicals 31: 9-16

Karlsson R, Fagerstam L, Nilshans H, Persson B 1993: Analysis of active antibody concentration separation of affinity and concentration parameters. J Immunol Methods 166: 75-84

King AA 1996: Cell culture of rabies virus. In: Meslin F-X, Kaplan MM, Koprowski H (Eds.) Laboratory Techniques in Rabies. World Health Organization Press, Geneva, Switzerland, pp.114-130

Kumbhat S, Sharma K, Gehlot R, Solanki A, Joshi V 2010: Surface plasmon resonance based immunosensor for serological diagnosis of dengue virus infection. J Pharmaceut Biomed 52: 255-259

Niezgoda M, Rupprecht CE 2006: Standard operating procedure for the direct rapid immunohistochemistry test for the detection of rabies virus antigen. In: National Laboratory Training Network Course. US Department of Health and Human Services, Centers for Disease Control and Prevention Press, Atlanta, pp. 1-16

Rodney EW, Kelly ST, George MH, Nancy SG, Catherine MA, Michael JS, Michael JC, and Charles ER 2005: Survival after treatment of rabies with induction of coma. N Engl J Med 352: 2508-2514

Rosenbaum MJ, Edwards EA, Sullivan EJ 1970: Micromethods for respiratory virus seroepidemiology. Health Lab Sci 7: 42-53

Sambrook J, Fritsch EF, Maniatis T 1989: Molecular Cloning. A Laboratory Manual, $2^{\text {nd }}$ Edition. Cold Spring Harbor Laboratory Press, New York, pp. 1860-1875

Thomsen V, Schatzlein D, Mercuro D 2003: Limits of detection in spectroscopy. Spectroscopy 18: 112-114

Zhang SF, Gao L, Zhang F, Li HT, Li QZ, Hu RL 2006: Establishment and application of hybridomas producing anti-rabies nucleoprotein McAb and fluorescent antibody virus neutralization test. Chin J Lab Med 29: 554-557

Zhang SF, Liu Y, Zhang F, Hu RL 2009: Competitive ELISA using a rabies glycoprotein-transformed cell line to semi-quantify rabies neutralizing-related antibodies in dogs. Vaccine 27: 2108-2113 